European Journal

\title{
of Management Issues
}

Volume 27(1-2), 2019, pp.21-28

DOI: $10.15421 / 191903$

Received: 22 January 2019

Revised: 07 March 2018; 13 April 2019

Accepted: 06 May 2019

Published: 25 June 2019

UDC classification: 658

JEL Classification: M11, P49, M10, F64, 033

\section{Система управління сталим розвитком підприємства готельно- ресторанного господарства на основі моніторингу витрат}

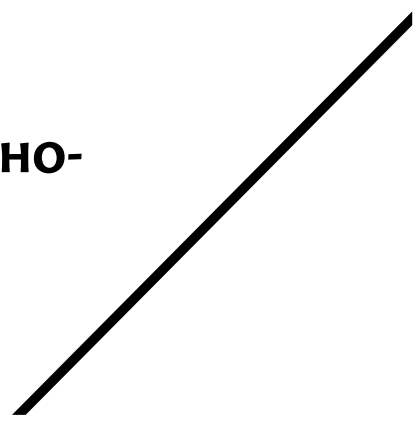

О. І. Юдіна

Мета роботи - сформувати та обґрунтувати оптимальну модель системи управління сталим економічним розвитком підприємства готельно-ресторанного господарства.

Аизайн/Метод/Підхід дослідження. Теоретичне узагальнення, логіко-критичний і економіко-математичний аналіз закономірностей функціонування підприємства як економічної системи, що базується на системному, процесному та цільовому методичних підходах.

Результати дослідження. Досліджено закономірності функціонування підприємства як економічної системи. Розглянуто системний, цільовий та процесний підходи до управління суб'єктом господарювання, шляхом розробки методології по формуванню цільових функцій його окремих підсистем і процесів. Розглянуто системний, цільової і процесний підходи до управління суб'єктом господарювання шляхом розробки методології, пов'язаної з формуванням цільових функцій окремих підсистем і процесів, що складають господарську діяльність, для виявлення закономірностей їх взаємодії та досягнення інтегрованого результату з найбільшою ефективністю. Сформовано структурно-логічну модель системи управління під впливом збурюючих факторів зовнішнього середовища на основі цільових функцій і встановлених векторів стійкого економічного розвитку підприємства готельно-ресторанного господарства з урахуванням моніторингу показників його діяльності.

Практичне значення дослідження. Результати дослідження дозволяють сформувати цільову систему управління сталим економічним розвитком підприємства готельно-ресторанної сфери на основі моніторингу витрат, як елементів спожитих ресурсів, і ефективно адаптувати до змін навколишнього середовища за допомогою інтеграції техніки, технології, економічних процесів, методів планування і управління.

Оригінальність/Цінність/Наукова новизна дослідження. Запропоновано методику формування системи управління сталим економічним розвитком підприємства готельно-ресторанної сфери на основі моніторингу витрат, яка, на відміну від існуючих, базується на сукупності системного, процесного та цільового підходів та дає змогу шляхом диференціювання процесів, що відбуваються на підприємстві, й встановлення закономірностей їх функціональних зв'язків з показниками витрат ресурсів, забезпечити прогнозування і планування результатів діяльності.

Обмеження дослідження/Перспективи подальших досліджень. Ці дослідження $\epsilon$ основою для подальшої оцінки і прогнозування ефективності функціонування, оптимізації витрат ресурсів виробничо-комерційної діяльності суб'єкта господарювання, створення механізму сталого економічного розвитку підприємства.

Тип статті - теоретичний.

Ключові слова: готельно-ресторанний бізнес; цільове управління; сталий економічний розвиток; системний та процесний підходи.

‡Олена Іванівна Юдіна Вищий приватний навчальний заклад "Дніпровський гуманітарний університет», Дніпро, Україна, E-mail: el.judina@gmail.com, https://orcid.org/0000-0003-3699-5321

\section{Reference to this paper should be made as follows:}

Judina, O. I. (2019). Management system the sustainable development of enterprise of hotel and restaurant business based on cost monitoring. European Journal of Management Issues, 27(1-2), 21-28. doi:10.15421/191903. 


\section{Management system the sustainable development of enterprise of hotel and restaurant business based on cost monitoring}

\section{Olena Ivanivna Judina ${ }^{\ddagger}$}

\#Higher Educational Institution «Dnipro Humanities University», Dnipro, Ukraine

Purpose - to formulate and justify the optimal system model for managing sustainable economic development of a hotel and restaurant business.

Design/Method/Approach. A theoretical generalization, logicalcritical and economic-mathematical analysis patterns of functioning of a business as an economic system, based on systemic, process and target methodological approaches.

Findings. The regularities of the business operating as an economic system are investigated. The system, target and process approaches to managing a business entity by developing a methodology related to the target functions formation of the individual subsystems and processes that make up the business activity are studied to identify patterns of their interaction and achieve an integrated result with the greatest efficiency. A structural-logical model of the control system is formed under the influence of disturbing environmental factors based on the objective functions and established vectors of sustainable economic development of the hotel and restaurant business, taking into account monitoring of its performance.

Practical implications. The research results allow formulating the target management system for the sustainable economic development of the hotel and restaurant businesses based on monitoring costs as elements of the resources consumed, and effectively get adapted to environmental changes through integration of engineering, technology, economics, planning and management methods.

Originality/Value. There was proposed a method for the system formation for managing sustainable economic development of a hotel and restaurant business based on cost monitoring, which, unlike existing ones, based on a set of system, process and target approaches and enables by differentiation processes occurring within the business and establishing patterns of their functional links with indicators of resource costs, provide forecasting and planning of performance.

Research limitations/Future research. These researches are the basis for the subsequent evaluation and prediction of the of the operation efficiency, optimize resource costs of production and commercial activities of business entities, to create a mechanism for sustainable development of businesses.

Paper type - theoretical.

Keywords: hotel and restaurant business; target management; sustainable economic development; system and process approaches.

\section{Система управления устойчивым развитием предприятия гостинично- ресторанного хозяйства на основе мониторинга затрат}

\section{Елена Ивановна Юдина}

¥Высшее частное учебное заведение «Днепровский гуманитарный университет», Днепр, Украина

Цель работы - сформировать и обосновать оптимальную модель системы управления устойчивым экономическим развитием предприятия гостинично-ресторанного хозяйства.

Аизайн/Метод/Подход исследования. Теоретическое обобщение, логико-критический и экономико-математический анализ закономерностей функционирования предприятия как экономической системы, базирующийся на системном, процессном и целевом методических подходах.

Результаты исследования. Исследованы закономерности функционирования предприятия как экономической системы. Рассмотрены системный, целевой и процессный подходы к управлению субъектом хозяйствования путем разработки методологии, связанной с формированием целевых функций отдельных подсистем и процессов, составляющих хозяйственную деятельность, для выявления закономерностей их взаимодействия и достижения интегрированного результата с наибольшей эффективностью. Сформирована структурно-логическая модель системы управления под воздействием возмущающих факторов внешней среды на основе целевых функций и установленных векторов устойчивого экономического развития предприятия гостиничноресторанного хозяйства с учетом мониторинга показателей его деятельности.

Практическое значение исследования. Результаты исследования позволяют сформировать целевую систему управления устойчивым экономическим развитием предприятия гостинично-ресторанной сферы на основе мониторинга затрат, как элементов потребленных ресурсов, и эффективно адаптировать к изменениям окружающей среды с помощью интеграции техники, технологии, экономики, методов планирования и управления.

Оригинальность/Ценность/Научная новизна исследования. Предложена методика формирования системы управления устойчивым экономическим развитием предприятия гостинично-ресторанной сферы на основе мониторинга затрат, которая, в отличие от существующих, базируется на совокупности системного, процессного и целевого подходов и дает возможность путем дифференцирования процессов, происходящих на предприятии, и установления закономерностей их функциональных связей с показателями затрат ресурсов, обеспечить прогнозирование и планирование результатов деятельности.

Ограничения исследования/Перспективы дальнейших исследований. Эти исследования являются основой для последующей оценки и прогнозирования эффективности функционирования, оптимизации затрат ресурсов производственно-коммерческой деятельности субъектов хозяйствования, разработки механизма устойчивого развития предприятий.

Тип статьи - теоретический.

Ключевые слова: гостинично-ресторанный бизнес; целевое управление; устойчивое экономическое развитие; системный и процессный подходы. 


\section{1. Вступ}

ьогодні в складних економічних, політичних, соціальних та С фінансових умовах функціонування підприємств в країні й в світі виникає необхідність у переході на стійке функціонування суб'єктів господарювання, що забезпечує їх стабільний розвиток і захист від негативного впливу зовнішніх і внутрішніх факторів. Сталий економічний розвиток підприємства готельно-ресторанної сфери - це комплексне поняття, як і сама господарська діяльність, що залежить від наявності ресурсів, ефективності їх використання, тобто зниження ресурсомісткості та підвищення рентабельності продукції (товарів, послуг), а також від наявності гнучкої організаційної структури і життєздатної системи управління.

На даний час проблематиці сталого розвитку, як предмету дослідження теоретичного і прикладного характеру, приділяється пильна увага багатьох вчених. Наукові роботи вітчизняних і зарубіжних авторів присвячені розробці теоретичних і методологічних основ концепції сталого розвитку в різних їі аспектах - політичних, екологічних, організаційних, фінансових, економічних. Глобальний мир зіткнувся 3 необхідністю переходу на стійкий шлях розвитку, що забезпечує позитивні зміни в соціально-економічних системах у взаємодії з навколишнім середовищем в довгостроковій перспективі, та їх захист від природних і штучних соціальних, економічних криз в умовах негативних подій.

Дослідженню проблеми економічного розвитку підприємства та управління цим процесом присвячено роботи багатьох вітчизняних і зарубіжних науковців, зокрема: J. Miltenburg (2013), R. Menda (2014), l. Chajkivs'kyj (2014), V. Lyashenko (2014), V. Vasylenko (2014), O. Balakireva, V. Heyets', \& V. Sidenko, et al (2014)., A. Goncharov (2015), R. Holzmann, R. Paul, \& H. Dorfman (2015), T. Kravchenko (2015), L. Tomialojts (2015), C. Roland, T. Atamer, \& P. Nunes (2015), N. Afanas'yev, V. Rogozhin, \& V. Rudyka (2015), O. Bobrova, V.M. Andrushkiv, \& L. M. Mel'nyk (2016), M. Medvid' (2016), O. Bobrovs'ka (2016), L. Volkova (2016), Yu. Kharazishvili, V. Lyashenko (2017), I. Malaykina (2018), N. Kyrych, S. Spivak (2018) та інших.

В. Ляшенко визначив економічний розвиток як процес, під час якого відбуваються зміни в соціально-економічній системі за рахунок накопичення потенціалу, причому ці зміни стосуються як системи в цілому, так і окремих її елементів, можуть носити як кількісний, так і якісний характер, забезпечуються відповідною діяльністю і в кінцевому підсумку сприяють досягненню поставленої мети і задоволенню економічних потреб суб'єктів (Lyashenko, 2014). Т. Кравченко «управлінням розвитком підприємства» пояснив як процес подолання суперечностей між економічним зростанням, збереженням природних ресурсів та поліпшенням якості життя населення (Kravchenko, 2015). О.Балакрієва та колектив авторів приділили увагу управлінню розвитком продуктивних сил на довгостроковому інтервалі й вважає їх основним фактором економічного розвитку (Balakireva, Heyets', Sidenko, et al., 2014).

У національній парадигмі сталого розвитку України (Ed. Paton, 2013) категорію «управління економічним розвитком» охарактеризовано як системне узгодження, збалансованість складових елементів і процес розробки на цій основі стратегії сталого розвитку господарських утворень. Б. Андрушків і Л. Мельник спробували протрактувати термін «сталий розвиток підприємства» базуючись на системно-інтегрованому підході та вважають, що його логіка для господарської одиниці виражається у задоволенні її потреб, тобто отриманні прибутку та покращенні іміджу на конкуруючому ринку, зростанні продуктивності праці, оптимізації енергоспоживання, зниженні відходів, підтримки з боку органів місцевого самоврядування, виході на зовнішні ринки (Andrushkiv \& Mel'nyk, 2016). Н. Кирич вважає, що економічний аспект сталого розвитку базується на теорії максимального потоку сукупного доходу, який може бути отриманий при збереженні сукупного капіталу, оптимальному використанні обмежених ресурсів і застосуванні нових технологій (Kyrych, 2018). М. Медвідь пов'язав управління сталим розвитком підприємства з економічністю (мінімізацією витрат) та результативністю (максимізацією результатів), що дозволяє задіяти в практику управління новий європейський досвід (Medvid', 2016). О. Бобровська визначає економічний розвиток як сукупність можливостей реалізації наявних ресурсів у господарської діяльності економічних суб'єктів (Bobrovs'ka, 2016). Н. Афанасьєв та колектив авторів під управлінням сталим розвитком підприємства розуміють процес формування нової властивості системи, що базується на забезпеченні зміни тільки ї̈ якісних характеристик (Afanas'yev, Rogozhin, \& Rudyka, 2015). На думку Ю. Харазішвілі та В.Ляшенко сталий розвиток інтегральна характеристика стану економічної системи, оскільки система включає ряд підсистем (найважливіших, взаємозв'язаних структурних складових розвитку економічної системи), які відображають функціонування окремих сфер економіки - економічної, соціальної екологічної (Kharazishvili \& Lyashenko, 2017). А.Гончаров наголосив, що розвиток економічної системи являє собою сукупність ресурсних потенціалів, організаційних здібностей до формування та економічної готовності до втілення конкретних заходів по досягненню економічною системою розвитку сталого типу (Goncharov, 2015). О.Боброва та І. Малайкина відмітили, що трактування терміну «сталий розвиток» сфокусовано на соціальній, економічній та екологічній сферах взаємовідносин суспільства і господарюючих суб'єктів та характеризує процес розвитку на макро-, мезо- і мікрорівні (Bobrova \& Malaykina, 2018). Л. Волкова під терміном «сталий розвиток підприємства» розуміє такий режим його функціонування, при якому, безумовно, виконуються оперативні, поточні й стратегічні плани роботи підприємства за рахунок реалізації на регулярній основі заходів щодо попередження, виявлення та нейтралізації ринкових загроз Аля виконання плану (Volkova, 2016). Л. Томялойц поєднує у понятті «сталий розвиток» економічне зростання і розвиток, які доповнюють один одне і не $\epsilon$ антагоністичними довкіллю та суспільству (Tomialojts, 2015). I. Чайківський визначив сутність сталого розвитку у спроможності за рахунок мобілізації своїх внутрішніх резервів створити таку раціональну структуру виробництва, яка 6 при прояві випадкових зовнішніх впливів сприяла пом'якшенню несприятливих наслідків і одержанню мінімальних відхилень від сформованої тенденції розвитку (Chajkivs'kyj, 2014). Р. Хольцман, P. Пол та Х. Дорфман характеризували сталий розвиток підприємства як його стійкість до зовнішніх шоків, що означає здатність системи адаптуватися до несподіваних змін економічних, демографічних і політичних умов (Holzmann, Paul, Dorfman, 2015). Р. Менда та Я. Мільтенбург запропонували цілісну методологію і деталізований процес створення виробничої стратегії, яка ґрунтується на результатах проведення аудиту і контролю економічної системи, що сприяє створенню виробничої стратегії розвитку підприємства (Menda, 2014; Miltenburg, 2013). На думку С. Роланда, Т. Атамера, П. Нунеса основні підходи до формування моделей регулювання економічного розвитку та підвищення конкурентоспроможності підприємств в ринкових умовах пов'язані з ефективністю використання ресурсів (Roland, Atamer, Nunes, 2015). Разом з цим у дослідженнях залишаються не розглянутими підходи щодо диференційованого вивчення складових процесу управління і формування інтегрованих цільових систем управління сталим економічним розвитком підприємства на основі моніторингу витрат та встановлення закономірностей зростання ефективності діяльності за функціональними ознаками.

\section{2. Постановка проблеми}

сучасних умовах невизначеності зовнішнього середовища У забезпечення сталого економічного розвитку підприємства готельно-ресторанної сфери входить до складу його найважливіших завдань і функцій, тому актуальним стає вирішення питання щодо формування цільової системи управління цим процесом. 
Meта дослідження - обґрунтувати та сформувати оптимальну модель системи управління сталим економічним розвитком підприємства готельно-ресторанного господарства на основі системного, процесного і цільового методичних підходів.

\section{3. Методи дослідження}

роботі застосовано системний, процесний і цільовий У підходи щодо створення системи управління сталим економічним розвитком підприємства готельноресторанного господарства на основі моніторингу витрат. Використано методи теоретичного узагальнення та критичного аналізу - при визначенні підходів щодо формування системи управління сталим економічним розвитком підприємства, графічний - для наочного подання результатів дослідження, економіко-математичний - для визначення закономірностей динамічних змін в економічній системі, логічний - для встановлення принципіальної структури, взаємозв'язків результатів дослідження, побудови та обґрунтування предмету наукового дослідження.

\section{4. Результати дослідження}

творення системи управління сталим економічним C розвитком господарюючих одиниць готельно-ресторанної сфери на основі моніторингу витрат ґрунтується на визначенні їх диференційованого та інтегрованого впливу як елементів спожитих ресурсів на ефективність результатів діяльності. Сукупність використовуваних ресурсів формує ресурсний потенціал підприємства, що забезпечує мобілізацію наявних можливостей інтеграції взаємозв'язаних i взаємодіючих ресурсів підприємства з урахуванням ступеня їх взаємного впливу. Таким чином, підвищується продуктивність системи потенціалів, яка $\epsilon$ більш ефективною, чим проста сума елементів. При цьому підвищення ефективності використання ресурсів зумовлює зниження витрат, а їх моніторинг сприяє проведенню структурно-компонентного аналізу показників за напрямами діяльності, що забезпечують сталий економічний розвиток підприємства готельно-ресторанної сфери.

В ході моніторингу визначають фактори, що впливають на варіабельність процесу управління, в якому використовують науково-обґрунтовані принципи, методи і підходи.

Динамічність, нестабільність і невизначеність сучасних умов функціонування підприємств готельно-ресторанного бізнесу викликають необхідність раціонального і ефективного управління їх виробничо-комерційною діяльністю 3 урахуванням всіх взаємодіючих елементів економічної системи господарюючих одиниць.

В рамках вирішення цієї проблеми доцільне використання принципів системного підходу.
Системний підхід використовують у взаємодії з цільовим підходом, який ґрунтується на розробці методології формування цільових функцій окремих блоків і процесів, які складають господарську діяльності для досягнення інтегрованого оптимального результату 3 найбільшою ефективністю.

Управління на основі цих підходів спрямоване на визначення та забезпечення ефективнішої взаємодії всіх елементів або підсистем і складових процесів соціально-економічної системи.

3 наукової точки зору підприємство як система складається і характеризується певними властивостями, до яких відносяться:

- цілісність і роздільність на складові частини, тобто система представляє цілісну сукупність елементів, що взаємодіють один з одним і виконують певні функції для отримання заданих результатів (елементи системи можуть бути якісно різними, але відповідати умовам сумісності);

- наявність взаємозв'язків окремих елементів системи, що забезпечують ії інтеграційні властивості;

- наявність у системи сукупних якостей, що визначають їі властивості в цілому;

- наявність впорядкованої організаційної структури (Volkova, 2016).

Тобто підприємство готельно-ресторанного господарства $\epsilon$ системою, в якій відображається технічна, економічна і організаційна єдність керованого об'єкту, і кожен елемент системи знаходиться під впливом вхідних дій та, у свою чергу, формує вихідні дії (Рис. 1).

Вхідною дією Е, або входом, називається дія, що поступає на вхід від сукупності елементів $e_{i}(t)$, а вихідною дією $X$ або виходом, називається вихідна дія, що виробляється сукупністю елементів $y_{i}(t)$ на виході.

Підприємства готельно-ресторанного бізнесу як відкриті системи мають різні виробничі, технологічні й організаційні структури, які складаються 3 сукупності елементів та функціонують за певними економіко-математичними законами. Для підтримки їх в рівноважному стані, а також для забезпечення прогресивного розвитку суб'єкта господарювання необхідно здійснювати моніторинг і контроль економічних показників, що відображають рівень його економічної стійкості. Здійснення господарських операцій підприємством пов'язано з виконанням наступних функції: виробничої, комерційної, адміністративно-збутової (маркетингової), фінансової, кадрової, інноваційноінвестиційної та ін., які потребують витрат певних видів ресурсів, що характеризують входи системи, а також являють собою її елементи.

На практиці будь-яка система знаходиться під впливом обурень. Обурюючою дією $g(t)$ називається несподіваний вплив на елементи системи факторів зовнішнього середовища, що динамічно змінюються (Vasylenko, 2014).

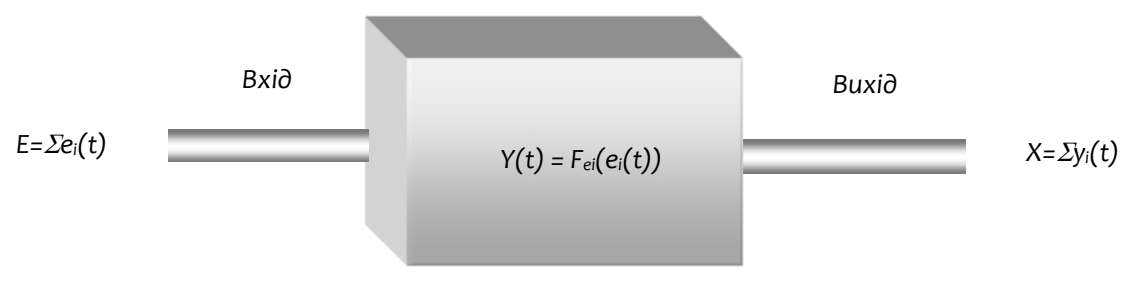

Рис. 1. Структурна схема підприємства готельно-ресторанного господарства як економічної системи 
У загальному випадку кожен елемент перманентно знаходитися в деякому русі, тобто в динамічному режимі, і в окремий момент часу $t$ елемент може характеризуватися конкретним станом, який можна представити у вигляді функціональної економіко-математичної залежності:

$$
Y(t)=F e(e(t))
$$

де $\mathrm{Fe}$ - функція, що описує поведінку елементу залежно від вхідної дії (впливу фактору).

Властивості окремого елементу описуються певними статичними і динамічними характеристиками, що впливають на сталий розвиток підприємства готельно-ресторанного типу. Особливості економічних систем, умов їх функціонування, разом з різноманіттям структур систем управління зумовлює сукупність законів управління. Узгодженість функціональних підсистем суб'єкту господарювання (блоків, підрозділів, напрямів діяльності, що виконуються за рахунок споживання певних видів ресурсів) забезпечується процесами управління шляхом надання цілеспрямованої дії на всі його складові елементи для досягнення запланованих результатів, тобто виконання цільових функцій. При цьому у всіх випадках необхідно забезпечувати дві основні компоненти будь-якого управління - стійкість і якість керуючих і керованих систем, а, отже, і процесу функціонування підприємства.

Стійкість системи - це необхідна, але недостатня умова її ефективної роботи. Система повинна характеризуватися певною якістю, а якість управління $\epsilon$ властивістю, яка визначається:

- характеристиками руху системи до заданого цільового стану; - рівнем досягнення заданого стану (параметрів економічного розвитку) відповідно до встановлених цільових функцій (Andrushkiv, Mel'nyk, 2016).

Функції, що виконуються підприємством готельноресторанного господарства, носять системоутворюючий характер. Зміна функцій під впливом зовнішніх або внутрішніх імпульсів (факторів), викликає зміну цільової дії, а отже, механізму функціонування і організаційної структури економічної системи, як в прогресивному, так і регресивному напрямі розвитку. Крім того, функції системи відображають її призначення і мають цільову спрямованість на отримання запланованих результатів.

Підприємство готельно-ресторанного господарства як система має внутрішні й зовнішні зв'язки, які носять матеріальноречовинний, фінансовий, інформаційний, техніко-технологічний та інший характер, обумовлений сукупністю видів діяльності й потенціалами використовуваних ресурсів, а також закономірностям їх взаємодії. Зовнішні зв'язки забезпечуються вхідними (процеси, ресурси) і вихідними (результати діяльності) елементами, внутрішній стан характеризується організаційно-економічною структурою, яка залежить віА складу, якості, закономірностей та порядку зв'язку елементів відповідає виконуваним функціям, і під їх впливом забезпечує певні властивості та стан системи.

Таким чином, розподіл процесів управління дає можливість розглядати діяльність підприємства готельно-ресторанного господарства як систему, що складається 3 керуючої й керованої підсистем, зв'язаних між собою передачею перетворенням інформації. А якість функцій i структура взаємозв'язків компонентів системи впливають на ії стійкість та економічний розвиток. Для встановлення закономірностей взаємодії структурних компонентів та складових загальної системи управління, доцільно виразити параметри, що їх характеризують, у виді змінних цільової економікоматематичної функції (Puc. 2).

Застосовуючи економіко-математичні закони функціонування систем, керуючу систему Іс можна охарактеризувати і-мірним вектором управління:

$$
Y(t)=\left(y_{1}(t), y_{2}(t), \ldots, y_{i}(t)\right)^{t}
$$

де $y_{i}(t)$ - елементи вектору управління керуючої системи.

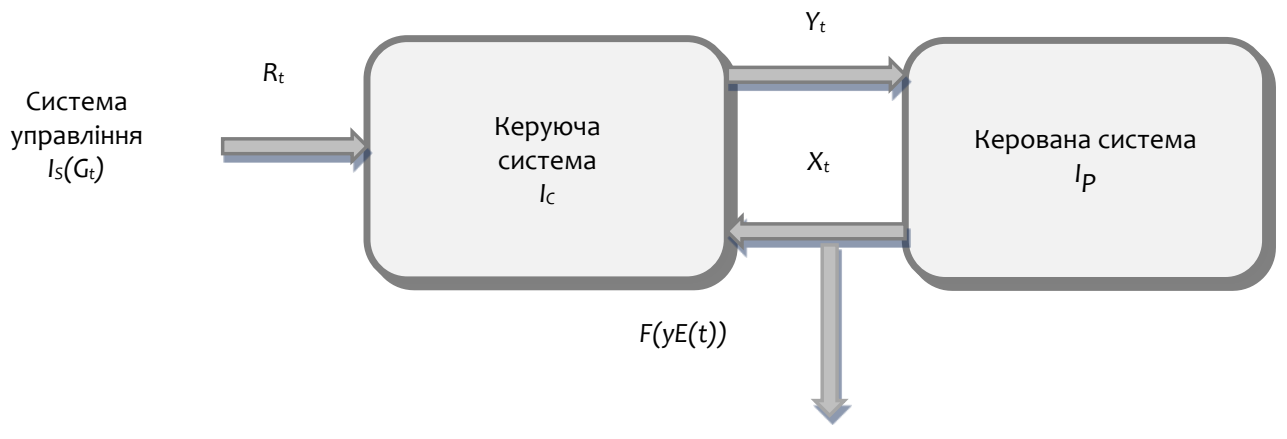

Рис. 2. Структура та зв'язки системи управління підприємством готельно-ресторанного господарства

Джерело: узагальнено автором.

Керована система IP в сукупності з керуючою системою $I_{c}$ утворюють систему управління, що представлена оператором Is.

Керована система знаходиться під впливом обурення t-мірного вектору:

$$
I_{s}=G(t)=\left(g_{1}(t), g_{2}(t), \ldots, g_{i}(t)\right)^{t}
$$

де $g_{i}(t)$ - елементи вектору системи управління $I_{s}$.
На керуючу систему Іс подається в загальному випадку n-мірний вектор задач (цілей):

$$
I_{C}=R(t)=\left(r_{1}(t), r_{2}(t), \ldots, r_{i}(t)\right)^{t},
$$

де $r_{1}(t)$ - елементи вектору задач керуючої системи Ic.

Відповідно до цього вектор управління $Y(t)$ формується залежно від змін значення розузгодження елементів (Vasylenko, 2014): 


$$
E(t)=R(t)-X(t),
$$

де $E(t)=\left(e_{1}(t), e_{2}(t), \ldots, e_{i}(t)\right)^{t}$ являє собою n-мірний вектор як функцію за цільовим призначенням $Y(t)=F(y(E(t))$.

Таким чином, параметри $E(t)$ можна вважати внутрішнім станом системи, а функцію $F(y(E(t))$ - економіко-математичною залежністю, що описує особливості й закономірності взаємодії процесів (елементів), які відбуваються в системі й спрямовані на отримання цільових результатів.

3 позиції підприємств стійкість можна розглядати як здатність системи зберігати свій працездатний стан щодо досягнення запланованих результатів при різних обурюючих діях (впливу факторів). Стійкість повинна забезпечуватися в будь-яких умовах і ситуація, що виникають у підприємства як економічної системи й в навколишньому середовищі (Vasylenko, 2014).

Для досягнення економічною системою протидії виникаючим обуренням, необхідно вирішити наступні завдання:

- виявити особливості самоорганізації системи і на основі функції цілі побудувати економіко-математичні моделі щодо визначення закономірностей взаємовпливу їі внутрішніх процесів (елементів), можливостей економічного зростання і прогресивного розвитку;

- сформувати механізм сталого економічного розвитку підприємства як системи;

- розробити концептуальну модель сталого економічного розвитку суб'єкту господарювання;

- розробити стратегічні напрями сталого розвитку підприємства (системи) з урахуванням закономірностей його функціонування і наявних ресурсних потенціалів.

Отже, управління підприємством готельно-ресторанного бізнесу як системою і окремими його елементами на основі системного підходу характеризується складними процесами взаємодії елементів різних підсистем, які задіяні в управлінні господарюючою одиницею.

Для формування системи управління сталим економічним розвитком підприємства готельно-ресторанного господарства на основі моніторингу витрат у сукупності з системним та цільовим підходами доцільно використання процесного, за допомогою якого досліджуються процеси, що відбуваються на підприємстві (тобто у економічній системі) та впливають на його сталий економічний розвиток за цільовим спрямуванням. У економічних і тлумачних словниках слово «процес» (від лат. processus - просування) тлумачиться як: 1) послідовна зміна станів стадій розвитку; 2) сукупність послідовних дій для досягнення будь-якого результату (Ekonomicheskiy slovar', 2018; Nechayev, Mikhaylushkin, 2016; Rossik, Klyuyev, 2015). В термінах міжнародного стандарту ISO 9000:2001 вказано, що «процес сукупність взаємозв'язаних або взаємодіючих видів діяльності, які перетворюють «входи» в «виходи» (DSTU ISO 9000-2001).

Найчастіше під процесом розуміється логічна послідовність дій в часі, що приводить до послідовної зміни проміжних станів системи, в якій цей процес протікає, а також перетворює початкові (вхідні) ресурси в кінцеві (вихідні результати) (Ekonomicheskiy slovar', 2018; Nechayev, Mikhaylushkin, 2016; Rossik, Klyuyev, 2015). Тобто процес характеризується протяжністю в часі, наявністю чітко визначених ресурсів, початкових і кінцевих подій, а також перехідних станів залежно від стадій процесу. Для процесу як певній сукупності й послідовності дій характерні: вхід, де використовуються початкові ресурси, i, як наслідок, створюються витрати, і вихід, що забезпечує результат.

При реалізації будь-якого процесу виникають зворотні зв'язки із зовнішнім середовищем, які, зокрема, носять й інформаційний характер. Моніторинг необхідної інформації дозволяє аналізувати та контролювати проведення бізнес-процесів, що спрямовані на досягнення мети і місії організації. Даний підхід до управління сприяє створенню організаційної структури, за допомогою якої можливе постійне удосконалення внутрішніх процесів і поліпшення якості кінцевого продукту, що сприяє підвищенню ефективності результатів діяльності підприємства готельно-ресторанного бізнесу, а, отже, і забезпечення його сталого економічного розвитку.

При цьому управління розглядається як процес, що складається з серії безперервних взаємозв'язаних дій, що в сукупності складають набір управлінських функцій, кожна з яких, у свою чергу, представляє процес. Таким чином, процес управління $\epsilon$ загальною сумою всіх функцій (Andrushkiv, Mel'nyk, 2016). А сам процесний підхід - це підхід, відповідно до якого, вся діяльність організації розглядається як сукупність взаємозв'язаних і взаємодіючих процесів (DSTU ISO 9000-2001). Застосування процесного підходу до управління витратами і економічним розвитком підприємства викликає необхідність ідентифікації та диференціації процесів, що відбуваються, визначення параметрів входів і виходів, встановлення певних вимог до процесів та їх взаємодії. При цьому метою управління сталим економічним розвитком суб'єкта господарювання на основі процесного підходу $\epsilon$ максимально можливе досягнення запланованих результатів найбільш ефективним способом шляхом максимізації прибутку та мінімізації витрат на прогресивній основі. Згідно процесного підходу модель системи управління сталим економічним розвитком на основі моніторингу витрат підприємства готельно-ресторанного господарства схематично зображено на Рис. 3.

У розробленої на базі процесного підходу моделі системи управління, що представлена на рисунку 3, система зв'язку утворює прямий канал передачі вхідної інформації $Y\left(I_{c}\right)$ зворотний канал передачі інформації про стан об'єкту управління керуючої системі $X\left(I_{P}\right)$.

На основі моніторингу, який включає збір, аналіз і оцінку інформації про стан економічних показників підприємства готельно-ресторанного бізнесу, керуюча система передає цільову керуючу дію на об'єкт управління. Використання зворотного зв'язку в процесному підході до управління дає можливість оцінити обурюючі дії факторів зовнішнього середовища та вплив цільової керуючої функції на елементи економічної системи (види діяльності, процеси, ресурси та ін.), здійснити прогнозування та оптимізацію процесів, що відбуваються, за допомогою створених економікоматематичних моделей та встановлених закономірностей взаємовпливу їх елементів. Таким чином, процесний підхід ґрунтується на таких практичних властивостях:

- зміна керованих параметрів входу забезпечує отримання заданих результатів цільової функції на виході;

- наявність об'єктивних і закономірних зв'язків між вхідними та результуючими показниками функціонування;

- можливість оцінки ступеня зміни результатів на виході за рахунок планування змін параметрів входу;

- можливість кількісного і якісного вибору процесів, їх інтеграції та інтерпретації.

Тобто процесний підхід до організації й управління підприємством орієнтує його діяльності на диференціювання бізнес-процесів, а систему управління - на управління як кожним бізнес-процесом окремо, так і всією їх сукупністю. Для забезпечення економічного зростання суб'єктів господарювання в сучасних умовах виникає необхідність у створенні єдиної системи, здатної ефективно адаптуватися до змін навколишнього середовища на основі інтеграції техніки, технології, економіки, методів планування і управління. 


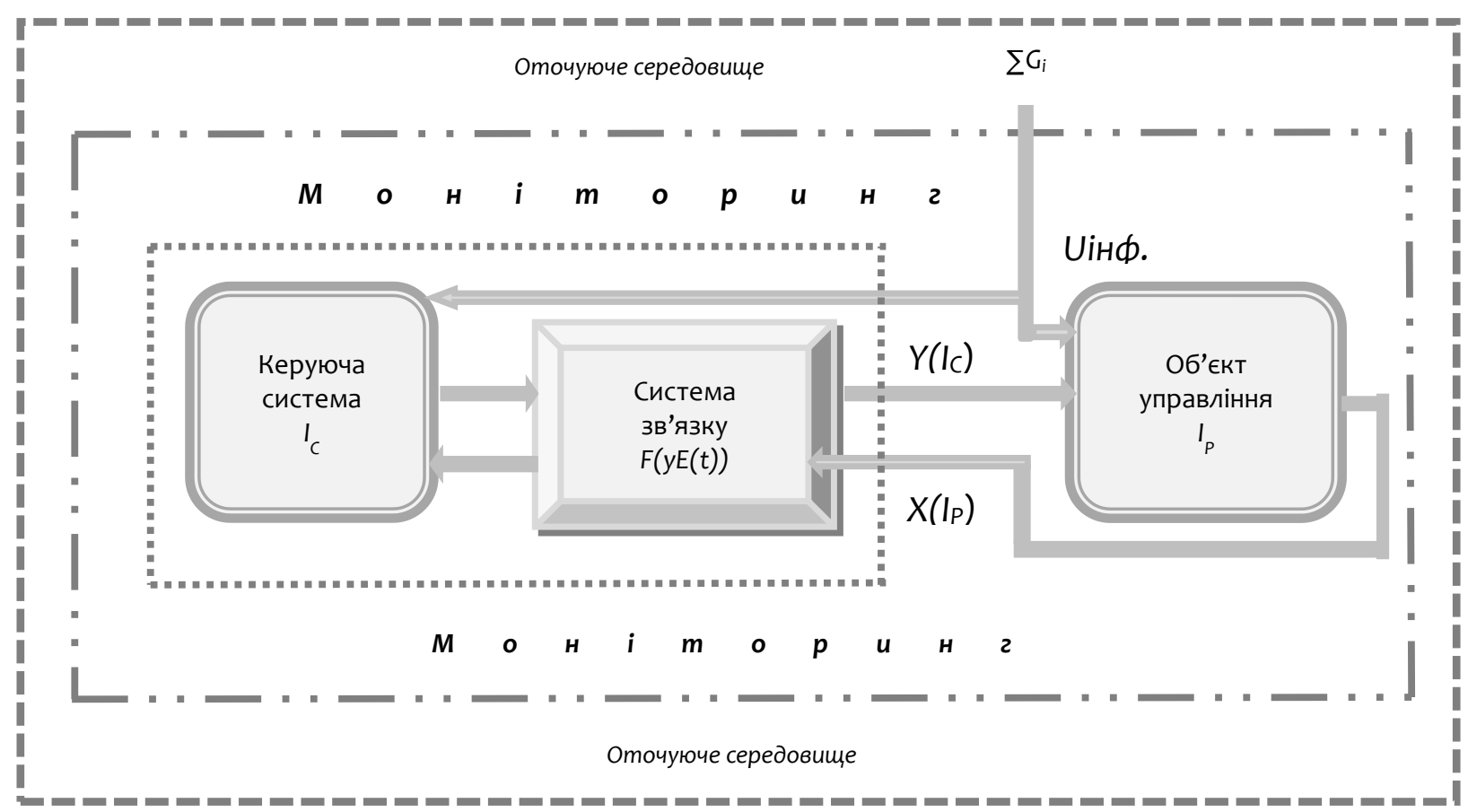

Рис. 3. Модель системи управління сталим економічним розвитком підприємства готельно-ресторанного господарства на основі моніторингу витрат

Джерело: розроблено автором.

\section{5. Висновки}

правлінська діяльність, що базується на системному, У процесному і цільовому методичних підходах, спрямована на приведення економічної системи (підприємства) в бажаний стан для забезпечення стійкого функціонування суб'єкта господарювання в зовнішньому середовищі впродовж тривалого періоду часу. Тому процес формування системи управління сталим економічним розвитком підприємства готельно-ресторанного господарства складається з таких елементів:

- визначення цілей та формулювання завдань сталого економічного розвитку підприємства;

- визначення сукупності елементів виробничо-комерційної діяльності та факторів, що впливають на їі ефективність;

- визначення методів оцінки економічної стійкості підприємства, використовуваних критеріїв і структури їх взаємодії;

- формування цільових напрямків економічного розвитку підприємства і порядку взаємодії впливаючих та результуючих показників взаємозв'язаних процесів;

- формування методології управління сталим розвитком підприємства на основі сукупності методів аналізу, оцінки, прогнозування, моніторингу і контролю.

Таким чином, застосування запропонованих методичних підходів в управлінні підприємством сфери готельноресторанного бізнесу, спрямовано на формування оптимальної цільової системи управління, яка дозволяє встановити взаємозв'язки між процесами, що відбуваються, і економічними показниками, які їх характеризують, збільшити ефективність виробничо-збутової діяльності, раціоналізувати організаційну структуру, підвищити швидкість ухвалення управлінських рішень і гнучкість реагування на зміну впливаючих факторів зовнішнього і внутрішнього середовища, а отже, забезпечити сталий розвиток суб'єкта господарювання.

Отримані результати дослідження забезпечують можливості для побудови економіко-математичних моделей на основі функції цілі, що описують кількісний диференційований та інтегрований вплив факторів (елементів системи) на результати (вихід системи), проведення моніторингу, аналізу, оцінки, прогнозування і планування величини показників діяльності підприємства, що, в свою чергу, дає змогу сформувати стратегію і ефективний механізм управління його сталим економічним розвитком.

\section{References}

Afanas'yev, N. V., Rogozhin, V.D., \& Rudyka, V.l. (2015). Upravleniye razvitiyem predpriyatiya: monografiya [Enterprise Development Management: monograph], Izdatel'skiy dom «INZHEK», Kharkiv (in Ukraine).

Andrushkiv, V.M., Mel'nyk, L. M. (2016). Kontseptual'ni polozhennya otsinyuvannya rivnya dosyahnennya staloho rozvytku pidpryyemstva [Conceptual provisions for assessing the level of achievement of sustainable enterprise development], Materialy Vseukrayins'koyi naukovopraktychnoyi konferentsiyi «Aktual'ni problemy ta perspektyvy staloho rozvytku pidpryyemstv ta rehioniv Ukrayiny", Dnipropetrovs'k, DHU, $122-124$ (in Ukrainian).

Balakireva, O. M., Heyets', V. M., Sidenko, V. R., et al (2014). Tsinnisna skladova modernizatsiyinykh protsesiv u suchasnomu sotsiumi Ukrayiny: monografiia [The value component of modernization processes in contemporary society of Ukraine: monograph], IEP NAN Ukrayiny, Kyiv (in Ukrainian).

Bobrova, O. S., Malaykina, I. V. (2018). Ustoychivoye razvitiye: kak yego ponimayut energeticheskiye kompanii [Sustainable development: how energy companies understand it], Vestnik YUUrGU, Seriya «Ekonomika i menedzhment», T. 12, 1, 63-79 (in Russia).

Bobrovs'ka, O. (2016). Stalyy rozvytok rehioniv Ukrayiny: problemy i shlyakhy yikh rozv"yazannya [Sustainable development of Ukrainian regions: problems and ways of solving them], Publichne upravlinnya: teoriya ta praktyka: elektronyy zbirnyk naukovykh prats', 1 (15), URL: http://www.dridu.dp.ua/zbirnik/2016-01(15)/15.pdf Ukrainian). 
Chajkivs'kyj, I. A. (2014). Mekhanizmy zabezpechennya staloho rozvytku sil's'kohospodars'kykh pidpryyemstv [Mechanisms for providing sustainable development of agricultural enterprises]. Naukovo-vyr. zhurnal "Innovatsijna ekonomika", 6 (55), 108-114 (in Ukrainian).

DSTU ISO 9000-2001. Systemy upravlinnya yakistyu. Osnovni polozhennya i slovnyk [Quality management systems. Essentials and Dictionary]. URL: https://dnaop.com/html/41056/doc\%D0\%94\%Do\%A1\%Do\%A2\%Do \%A3_ISO_9000-2001.

Ekonomicheskiy slovar' (2018). [Economic Dictionary] / Ed. A.I. Arkhipova. M.: Prospekt, 672 (in Russia).

Goncharov, A. V. (2015). Ustoychivoye razvitiye regiona: potentsial, faktory, kriterii, indikatory [Sustainable development of the region: potential, factors, criteria, indicators], Kazanskaya nauka, Kazan', 1, 53-57 (in Russia).

Holzmann, R., Paul, R., Dorfman, H. (2015). Pension Systems and Reform Conceptual Framework / World Bank.

Kharazishvili, Y. M., \& Lyashenko, V. I. (2017). Problemy otsinky ta intehral'ni indeksy staloho rozvytku promyslovosti Ukrayiny $z$ pozytsiy ekonomichnoyi bezpeky [Problems of assessment and integral indices of sustainable development of the industry of Ukraine from the standpoint of economic secure], Ekonomika Ukrayiny, 2, 3-23 (in Ukrainian).

Kravchenko, T. A. (2015). Natsional'na systema indykatoriv staloho rozvytku yak vazhlyvyy instrument provadzhennya derzhavnoyi polityky u sferi realizatsiyi stratehiyi staloho rozvytku «Ukrayina - 2020» [National System of Sustainable Development Indicators as an Important Instrument for State Policy Implementation in the Sustainable Development Strategy "Ukraine 2020"], Universytet.s'ki naukovi zapysky, Khmel'nyts'kyy : KHUP, 1 (53), 257-266 (in Ukrainian).

Kyrych, N. B., Spivak, S. M. (2018). Indykatory staloho rozvytku rehionu [Indicators of sustainable development in the region], Materialy Mizhnarodnoyi naukovo-tekhnichnoyi konferentsiyi «Fundamental'ni ta prykladni problemy suchasnykh tekhnolohiy», Ternopil' (in Ukrainian).

Lyashenko, V.I. (2014). Finansovo-rehulyatorni rezhymy stymulyuvannya ekonomichnoho rozvytku: vvedennya $v$ ekonomichnu rezhimolohiyu: monohrafiya [Financial and Regulatory Regimes for Stimulating Economic Development: Introduction to Economic Regime: Monograph], NAN Ukrayiny, In-t ekonomiky prom-sti, Donets'k, 370 (in Ukrainian).
Medvid', M. Y. (2016). Metodolohichni osnovy ekonomichnoho rehulyuvannya rehional'noho rozvytku: avtoref. dys. na zdobuttya dok. ekon. nauk [Methodological bases of economic regulation of regional development], Chernihiv, 42 (in Ukrainian).

Menda, R. (2014). The role of a Manufacturing Audit in crafting the production system. International Journal of Operations\&Production Management, 9, 931.

Miltenburg, J. (2013). Manufacturing Strategy: How to Formulate and Implement a Winning Plan, Productivity Press, Portland, OR, 214.

Nechayev V. I., Mikhaylushkin P. V. (2016). Ekonomicheskiy slovar' [Economic Dictionary], Krasnodar: Prosveshcheniye-Yug, 463.

Paton, B. E. (Ed.) (2013). Natsional'na Paradygma Stalogo Rozvytku Ukrainy [National Paradigm of Sustainable Development of Ukraine], Kyiv, In-t ekonomiky pryrodokorystuvannya ta staloho rozvytku NAN Ukrayiny, 72 (in Ukrainian).

Roland, C., Atamer, T., Nunes, P. (2015). The Dynamics of International Competition. From Practice to Theory. London, 29-36.

Rossik, Y. Y., Klyuyev, F. V. (2015). Tolkovyy slovar' ekonomicheskikh terminov i ponyatiy [Explanatory Dictionary of Economic Terms and Concepts], M.: Feniks, 160 (in Russia).

Tomialojts, L. (2015). Stalyy rozvytok: superechnist' osnovnykh pidkhodiv [Sustainable development: the contradiction basic approaches], Elektronnyy resurs, URL: http://ecoethics.ru/neobhodimost-v-strogoy-ohrane-krupnyihuchastkov-evropeyskih-lesov (in Ukrainian).

Vasylenko, V.A. (2014). Ynnovatsyy y kreatyvnost' na predpryyatyyakh kak ymperatyv stabylyzatsyy ékonomyky: "Natsional'na ekonomika $v$ umovakh formuvannya novoyi finansovo-ekonomichnoyi arkhitektury svitu: monohrafiya" [Innovations and creativity at enterprises as imperative of stabilization of economy: "National economy in the conditions of formation of new financial and economic architecture of the world: monograph"], Poltava, PUET, 320, 207 - 232 (in Ukrainian).

Volkova, L. V. (2016). Formirovaniye mekhanizmov ustoychivogo razvitiya promyshlennogo predpriyatiya (na osnove retsirkulyatsii izdeliy): avtoref. dis. dok. ekon. nauk [Formation of mechanisms for sustainable development of an industrial enterprise (based on product recycling)], Novosibirsk (in Russia).

\footnotetext{
(cc) $\mathbf{E Y}$ This is an open access journal and all published articles are licensed under a Creative Commons «Attribution» 4.0.
} 